\title{
Retraction Notice
}

Title of retracted article: Investigation of Relation Vegetation and Some Soil Physico-Chemical Author(s): Characteristics in Three Rangeland Habitats

Esmali

Behnam Bahrami, Ardavan Ghorbani, Mohammad Jafari, Fereidoun Rezanezhad, Abazar

* Corresponding author. Email: b.bahrami31@gmail.com

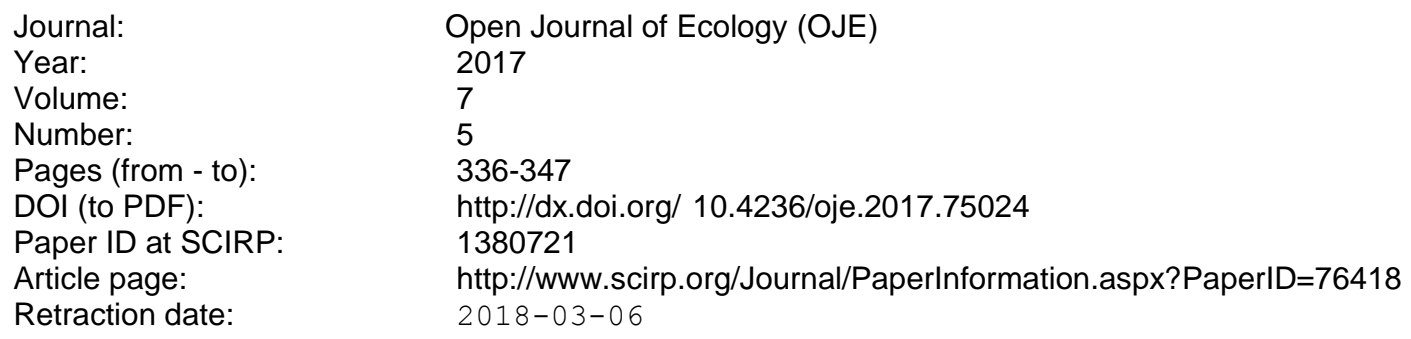

Retraction initiative (multiple responses allowed; mark with $\mathbf{X}$ ):

X All authors

$\square$ Some of the authors:

Editor with hints from

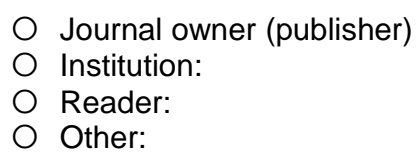

Retraction type (multiple responses allowed):

$\square$ Unreliable findings
O Lab error
Inconsistent data
Analytical error
Biased interpretation O Other:

$\square$ Irreproducible results

$\mathbf{X}$ Failure to disclose a major competing interest likely to influence interpretations or recommendations

$\square$ Unethical research

$\square$ Fraud
O Data fabrication
Fake publication
O Other:
Plagiarism
$\square$ Self plagiarism
$\square$ Other legal concern:
$\square$ Overlap
Redundant publication *
Copyright infringement
Editorial reasons
O Handling error
Unreliable review(s)
Decision error
O Other:

Other:

Results of publication (only one response allowed):

$\mathbf{X}$ are still valid.

$\square$ were found to be overall invalid.

Author's conduct (only one response allowed):

$X$ honest error

$\square$ academic misconduct

$\square$ none (not applicable in this case - e.g. in case of editorial reasons)

* Also called duplicate or repetitive publication. Definition: "Publishing or attempting to publish substantially the same work more than once." 


\section{History}

Expression of Concern:

Date (YYYY-MM-DD) : none Link:

Correction:

Date (YYYY-MM-DD) : none Link:

\section{Comment:}

The authors want to retract the paper for his own reason.

This article has been retracted to straighten the academic record. In making this decision the Editorial Board follows COPE's Retraction Guidelines. Aim is to promote the circulation of scientific research by offering an ideal research publication platform with due consideration of internationally accepted standards on publication ethics. The Editorial Board would like to extend its sincere apologies for any inconvenience this retraction may have caused.

The full retraction notice in PDF is preceding the original paper, which is marked "RETRACTED". 


\title{
Investigation of Relation Vegetation and Some Soil Physico-Chemical Characteristics in Three Rangeland Habitats
}

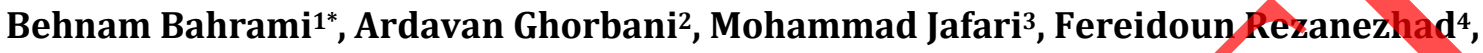 \\ Abazar Esmali2 \\ ${ }^{1} \mathrm{PhD}$ Student of Rangeland Department, Mohaghegh Ardabili University, Ardabil, Ira \\ ${ }^{2}$ Assosiated Professor of Rangeland and Watershed Management Department, University of Mohaghegh Ardabili, Ardabil, Iran \\ ${ }^{3}$ Professor of Rangeland Department, Tehran University, Tehran, Iran \\ ${ }^{4}$ Ecohydrology Research Group, Department of Earth and Environmental Sciences, University of Waterloo, Waterloo, Canada
} Email:*ardavanica@yahoo.com

How to cite this paper: Bahrami, B., Ghorbani, A., Jafari, M., Rezanezhad, F. and Esmali, A. (2017) Investigation of Relation Vegetation and Some Soil Physico-Chemical Characteristics in Three Rangeland Habitats. Open Journal of Ecology, 7, 336-347. https://doi.org/10.4236/oje.2017.75024

Received: January 27, 2017 Accepted: May 22, 2017 Published: May 25, 2017

Copyright $\odot 2017$ by authors and Scientific Research Publishing Inc This work is licensed under the Creative Commons Attribution International License (CC BY 4.0).

http://creativecommons.org/licenses/by/4.0/

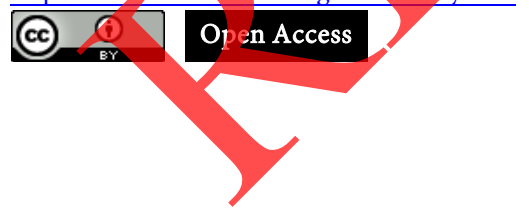

\section{Abstract}

Knowledge of the effect of ecological factors on establishment of vegetation distribution is crucial in the management of rangeland ecosystem. The aim of this study is to investigate relation between soil factors and plant species to determine the most effective factors between in three rangeland habitats; grassland, grassland-shrubland and shrubland in the Khanghah watershed of Urmia (Iran). The present species were recorded in each habitat using a randomized-systematic sampling method. In each habitat canopy cover and density of plant species were estimated within 30 quadrates of $1 \mathrm{~m}^{2}$ of located along 3 transect of $100 \mathrm{~m}$. The soil samples were taken from the depth of 0 15 and $15-30 \mathrm{~cm}$ of the soil within 30 quadrates. Soil properties organic carbon, particulate organic matter-carbon, soil organic matter, clay, silt, sand, $\mathrm{pH}, \mathrm{EC}$, bulk density, phosphorus, potassium and $\mathrm{CaCO}_{3}$ were measured. Relationships between soil factors and vegetation were determined using Multivariate techniques including Detrended Correspondence Analysis (DCA) and Canonical Correspondence Analysis (CCA). The results of the CCA showed that among soil factors, EC and Organic Matter are the most effective for describing the distribution of vegetation in three rangeland sites. In grassland habitat with reduction of nutrients, at first, grasses will replace the forbs and in the next stage, the grasses are replaced by shrubs. This trend is accompanied by decrease of organic matter, organic carbon, clay and silt. Ultimately the $\mathrm{pH}, \mathrm{EC}$, potassium, and $\mathrm{CaCO}_{3}$ rate will increase in the shrub land.

\section{Keywords}

Grassland, Grassland-Shrubland, Habitat, Soil Factors 


\section{Introduction}

Relationship between environmental parameter and vegetation cover is important to manage rangeland ecosystems and also helps to determine the main factors which can affect on vegetation cover changes. Vegetation is a main part of rangelands. Existence of each plants need to specific factors such as climate, topography and soil [1]. Investigating the relationship between plant species and environmental variables has been the aim of many ecological studies [2] [3].

Ecologists have documented that environmental variables may control plant species distribution and composition [4] [5]. Soil, is one of the most important environmental factors which affects the distribution and plant growths, and plays an important role in plant ecology [6]. The physical and chemical properties of soil, particularly in the rooting zone, play a very important role in shaping vegetation [7].

Thus, the distributions of vegetation more closely resemble to the changes in the soil characteristics [8]. Plants like animals and humans alike are attracted to locations where the site conditions are favourable to them, which suggest that differences in the distribution and abundance of plant species in any environment are an indication of the variation in soil properties [9] [10].

Several studies emphasized the influence of varying soil properties on the distribution and abundance of flora species in different locations [11] [12] [13] [14] [15].

Previous results, showed that the soil factors such as salinity, sand, sodium, potassium, magnesium and calcium, best correlated with distribution of vegetation in Failaka Island 16]. The results showed that the relationship of soil salinity with vegetation biomass, and that of soil salinity with available nitrogen were both negative [17]. Biomass was the main vegetation factor in indicating soil salinity.

According to previous results showed that distribution of communities is correlated with some soil variables (soil texture, soil moisture, organic matter, nitrogen and phosphorus [18]. Researches showed that the spatial distribution and densities tree/shrub species were selective with respect to varying soil properties [19].

The results, showed that the vegetation distribution was related to elevation, slope, and soil characteristics such as texture, organic matter, gypsum, acidity, lime, and gravity percentage [20].

Researcher reported that chemical properties such as organic matter and potassium and physical properties such as soil moisture and silt content caused increase soil fertility and consequently increased ecologic habitats in the soil [21].

The former results, Showed that Determination of the soil characteristics that are associated with each of xerophytic species can be used to determine which species is suitable for rehabilitating degraded sites in the study area [22]. Some results showed that soil texture, organic matter, gypsum, salinity, $\mathrm{C} / \mathrm{N}$ ratio, and elevation greatly affected the distribution of vegetation [23]. 
To better understand and manage rangeland ecosystems, it is important to study the relationship between environmental factors and plants in these ecosystems. The effects of environmental factors on plant Communities have been the subject of many ecological studies in recent years. In addition, soil-plant relationships have been studied [24] [25].

Thus, determining which factors control the presence, number, variety, and relative abundance of plant species remains a central goal in ecology. The main purpose of this study was to investigate the relationship between soil factors with plant species to determine the most effective factors separating in three rangeland habitats.

\section{Materials and Methods}

\subsection{Study Area}

The study was conducted in Khanghah watershed between latitudes $37^{\circ} 46^{\prime} 18^{\prime \prime} \mathrm{N}$ and $37^{\circ} 50^{\prime} 42^{\prime \prime} \mathrm{N}$ and longitudes $44^{\circ} 57^{\circ} 04^{\prime \prime} \mathrm{E}$ and $45^{\circ} 00^{\prime} 32^{\prime} \mathrm{E}$. Mean annual precipitation and temperature are $393.9 \mathrm{~mm}$ and $9.87^{\circ} \mathrm{C}$, respectively. In this study, 3 sites including grass land, shrub land, and grass-shrub land with the same geographical elevation and aspect were selected as shown in Figure 1.

\subsection{Data Collection}

The sampling process was conducted during May of 2015, when most species were expected to be growing. The present species were recorded in each habitat using a randomized-systematic sampling method. Vegetation sampling in each site has been done in the key area. In each habitat canopy cover, density and frequency of each plant species were estimated quantitatively using the transect and quadrate methods.

Density of plant species were estimated with in 30 quadrates of $1 \mathrm{~m}^{2}$ of located long 3 transect of $100 \mathrm{~m}$. In the area sampled, elevation, slope and aspect were recorded. Soilsamples were taken from the depth of $0-15$ and $15-30 \mathrm{~cm}$ in each quadrate. The soilsamples were transported to the laboratory and it characteristics were analyzed. Soil properties (Organic Carbon, POM-C ${ }^{1}$, Soil Organic Matter, Clay, Silt, Sand, pH, EC, Bulk Density, Phosphorus, Potassium and Ca$\mathrm{CO} 3$ were measured

\subsection{Data Analysis}

Relationships between soil factors and vegetation were determined using Multivariate techniques including Detrended Correspondence Analysis (DCA) and Canonical Correspondence Analysis (CCA).

DCA is an indirect gradient analysis technique; CCA is a direct gradient analysis. This technique greatly improves the power to detect specific effects of cross variable association and has been shown to be a robust model for detecting the relationship between species and their environment [26].

${ }^{1}$ particulate organic matter-carbon. 


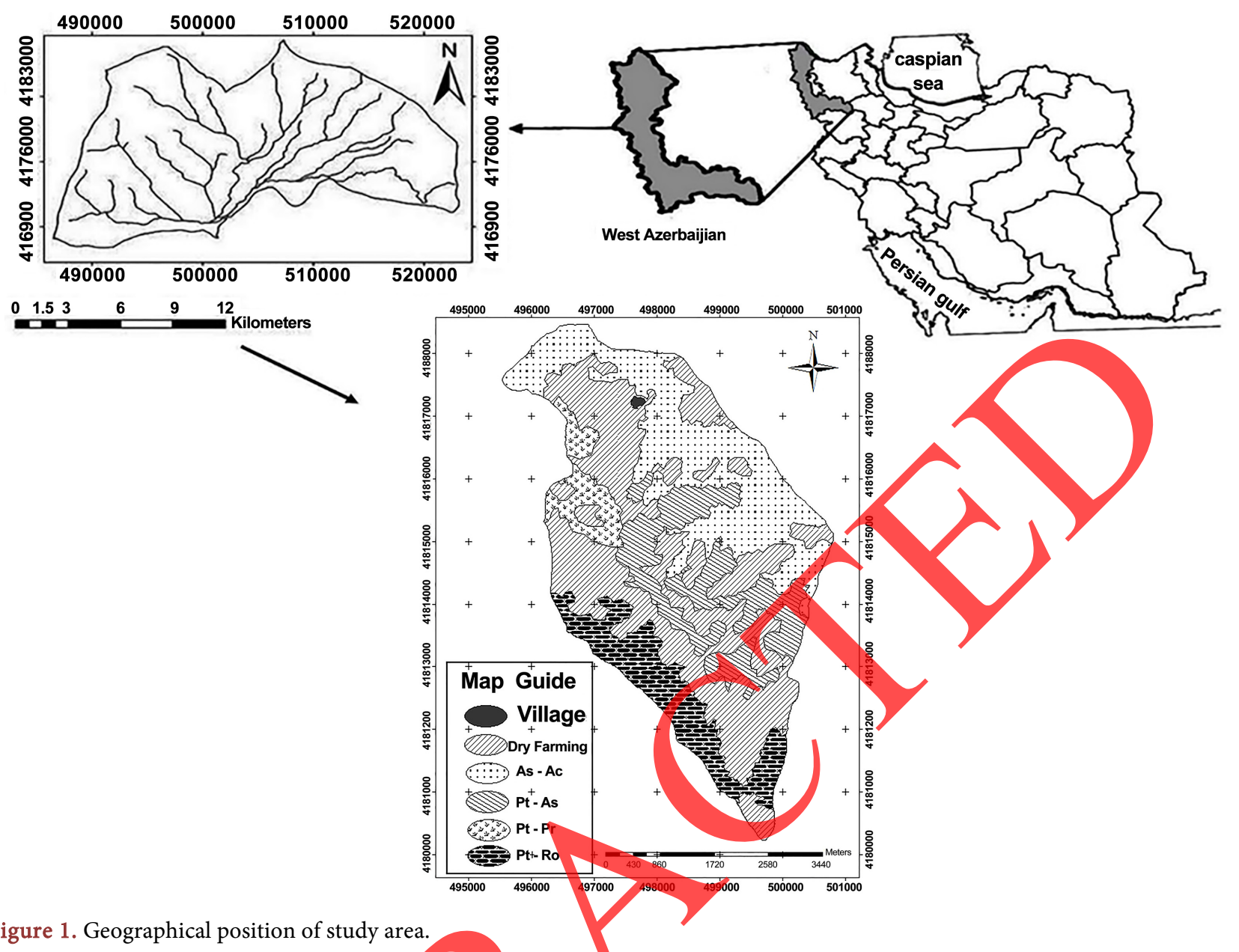

Figure 1. Geographical position of study area.

In the present study, Preliminary DCA analysis was made to check the magnitude of change in species composition along the first ordination axis (i.e., gradient length in standard deviation (SD) units). A gradient length greater than 4 SD indicates a strong unimodal response and the appropriateness of CCA.

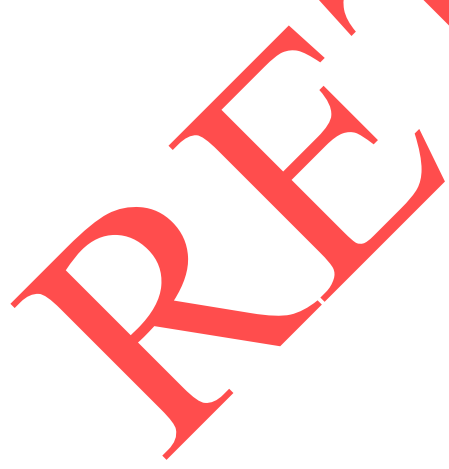

A analysis was used to determine the relationships between the floristic compositions and the soil variables in the study area. Distribution-free Monte Carlo test permutation (1000 permutations) was used to analyze signification of species-soil correlation and Eigen values of first canonical axis. Prior to analysis all variables were assessed for normality and appropriate transformations were performed. All ordinations, including DCA and CCA, were performed using CANOCO version 4.5 [27].

\section{Resulte}

\subsection{Detrended Correspondence Analysis}

The results of the DCA ordination are presented in Table 1. The eigenvalue of the strong first axis was 0.74 and of the second axis 0.50 . As shown in Table 1 , the first axis (eigenvalue $=0.74$ ) accounted for $10.6 \%$ of the variation in vegetation factors is by far the most important. Also gradient length estimated greater than 4 SD, which showed a modest unimodal response and thus the appro- 
priateness of CCA.

\subsection{Canonical Correspondence Analysis}

There was high correlation between some soil factors, because of that in this study, they were not entered in the analysis CCA. This correlation was observed between carbon and organic matter, thus organic carbon was removed from the calculations. Also was found a high correlation between the \%sand with \%clay and \%silt, that the \%sand was not entered in the calculations.

\subsection{CCA in First Layer ( 0 - 15)}

The results of CCA ordination in first layer $(0-15 \mathrm{~cm})$ are presented in Table 2 and Figure 2. The eigenvalue of the strong first axis was 0.57 and of the second axis 0.48. As shown in Table 2, the first axis (eigenvalue $=0.57$ ) accounted for $8.2 \%$ of the variation in soil factors and $95 \%$ coefficient of correlation of the environment-species is by far the most important (Table 2).

From the intra-set correlations of soil factors with the first three axes of CCA, it can be noted that CCA axis 1 was correlated to $\mathrm{pH}(\mathrm{r}=0.69), \mathrm{EC}(\mathrm{r}=0.73)$, Bulk Density $(r=0.65)$, Gypsum $(r=0.62)$, POM-C $(r=-0.45)$, Organic Matter $(\mathrm{r}=-0.41)$ and Silt $(\mathrm{r}=-0.38)$. While the CCA axis 2 was Correlated to potassium $(r=-0.55)$, phosphorus $(r=-0.37)$ and Clay $(r=-0.13)$ (Table 3$)$.

The results of Monte Carlo test showed that, in first layer $(0-15)$ among all soil factors, EC $(P<0.01)$ was the most influential features on the distribution of plants for this area. Also soil characteristics such as $\mathrm{pH}$, Gypsum and Bulk Density are the most effective for describing the distribution of vegetation in the study area. Also this factor (EC) showed a significant positive correlation with Astragalusgossypinus, Alyssumbracteatum and significant negative correlation with Trifoliumrepens, Chenopodiumalbum, Asperulaodorata, Coronillavaria, Campanula simplex and Bupleurumrotundifolium (Figure 2).

Table1. Results of DCA analysis for vegetation factors in the study area.

\begin{tabular}{ccccc}
\hline Axes & $\mathrm{DCA}_{1}$ & $\mathrm{DCA}_{2}$ & $\mathrm{DCA}_{3}$ & $\mathrm{DCA}_{4}$ \\
\hline Eigenvalue & 0.74 & 0.50 & 0.31 & 0.23 \\
Lengths of gradient & 4.85 & 3.92 & 2.85 & 2.18 \\
$\begin{array}{c}\text { Percentage of variance explained } \\
\text { Cumulative Percentage variance of } \\
\text { species data }\end{array}$ & 10.6 & 7.1 & 4.5 & 3.3 \\
\hline
\end{tabular}

Table 2. Results of CCA analysis for soil factors in depth $0-15 \mathrm{~cm}$.

\begin{tabular}{ccccc}
\hline Axes & $\mathrm{CCA}_{1}$ & $\mathrm{CCA}_{2}$ & $\mathrm{CCA}_{3}$ & $\mathrm{CCA}_{4}$ \\
\hline $\begin{array}{c}\text { Eigenvalue } \\
\text { Species-environment correlations }\end{array}$ & 0.57 & 0.48 & 0.39 & 0.32 \\
$\begin{array}{c}\text { Cumulative percentage variance } \\
\text { of species data }\end{array}$ & 8.2 & 14.4 & 20.0 & 24.6 \\
$\begin{array}{c}\text { Cumulative percentage variance } \\
\text { of species-environment relation }\end{array}$ & 21.2 & 37.0 & 51.4 & 63.4 \\
\hline
\end{tabular}




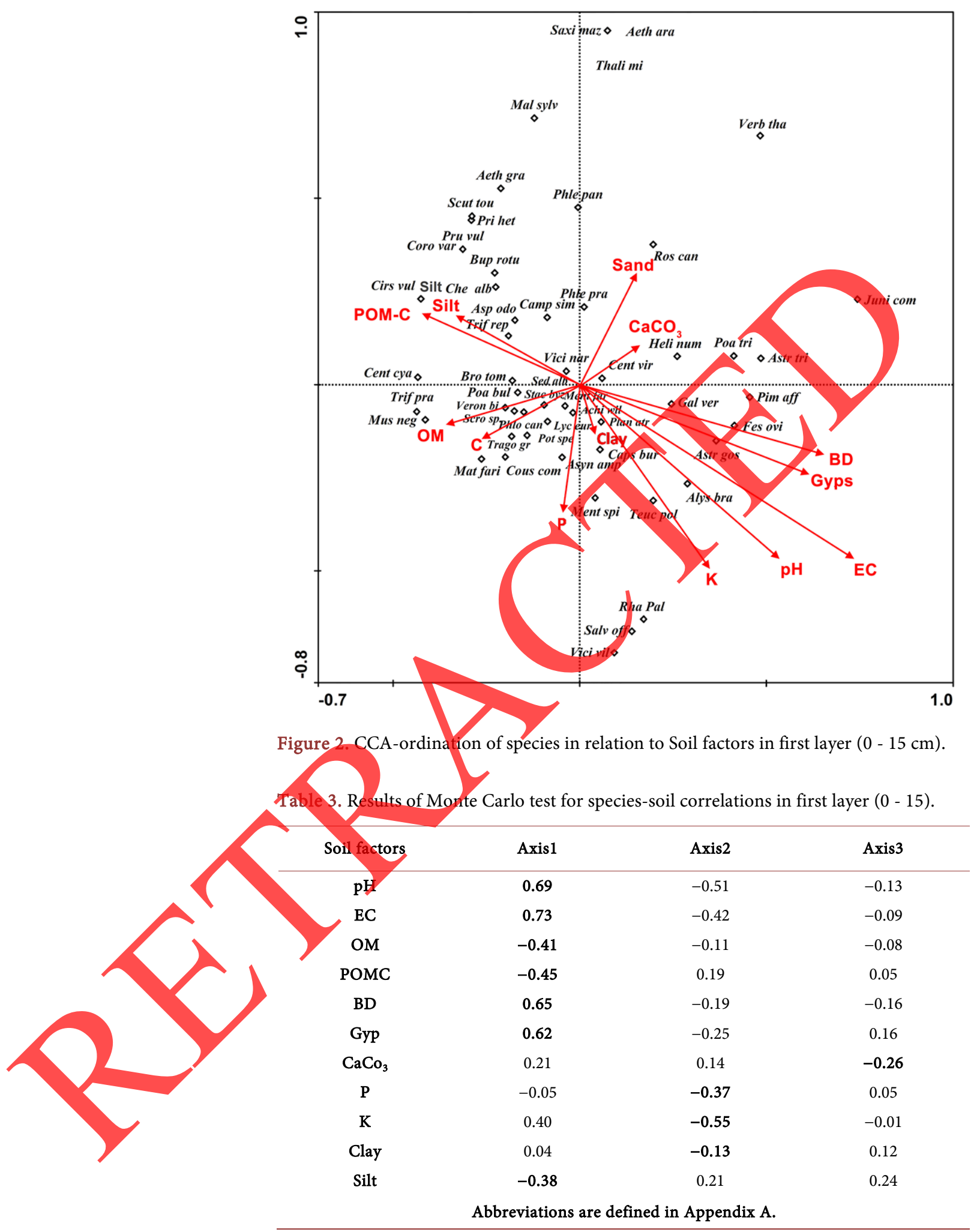

\subsection{CCA in First Layer (15 - 30)}

The results of CCA ordination in depth $15-30 \mathrm{~cm}$ are presented in Table 3 and Figure 3. Results of CCA analysis for soil factors in depth $15-30 \mathrm{~cm}$ are shown in Table 4 and the eigenvalue of the strong first axis was 0.59 and of the second 
axis 0.48 . As shown in Table 4 , the first axis accounted for $8.5 \%$ of the variation in soil factors and $96 \%$ coefficient of correlation of the environment-species is by far the most important (Table 4). From the intra-set correlations of soil factors with the first three axes of CCA, it can be noted that CCA axis 1 was correlated to Organic Matter $(\mathrm{r}=-0.82)$, EC $(\mathrm{r}=0.44), \mathrm{pH}(\mathrm{r}=0.25)$, Clay $(\mathrm{r}=-0.21)$ while the CCA axis 2 was Correlated to Potassium ( $r=-0.41)$, Bulk Density $(r=$ $-0.25), \mathrm{CaCO}_{3}(\mathrm{r}=0.24)$ and POM-C $(\mathrm{r}=-0.08)$. The results of Monte Carlo tests shown in Table 5 and that showed, in first layer (15 - 30) among all soil factors, Organic Matter $(P<0.01)$ was the most influential features on the distribution of plants for this area (Table 5).

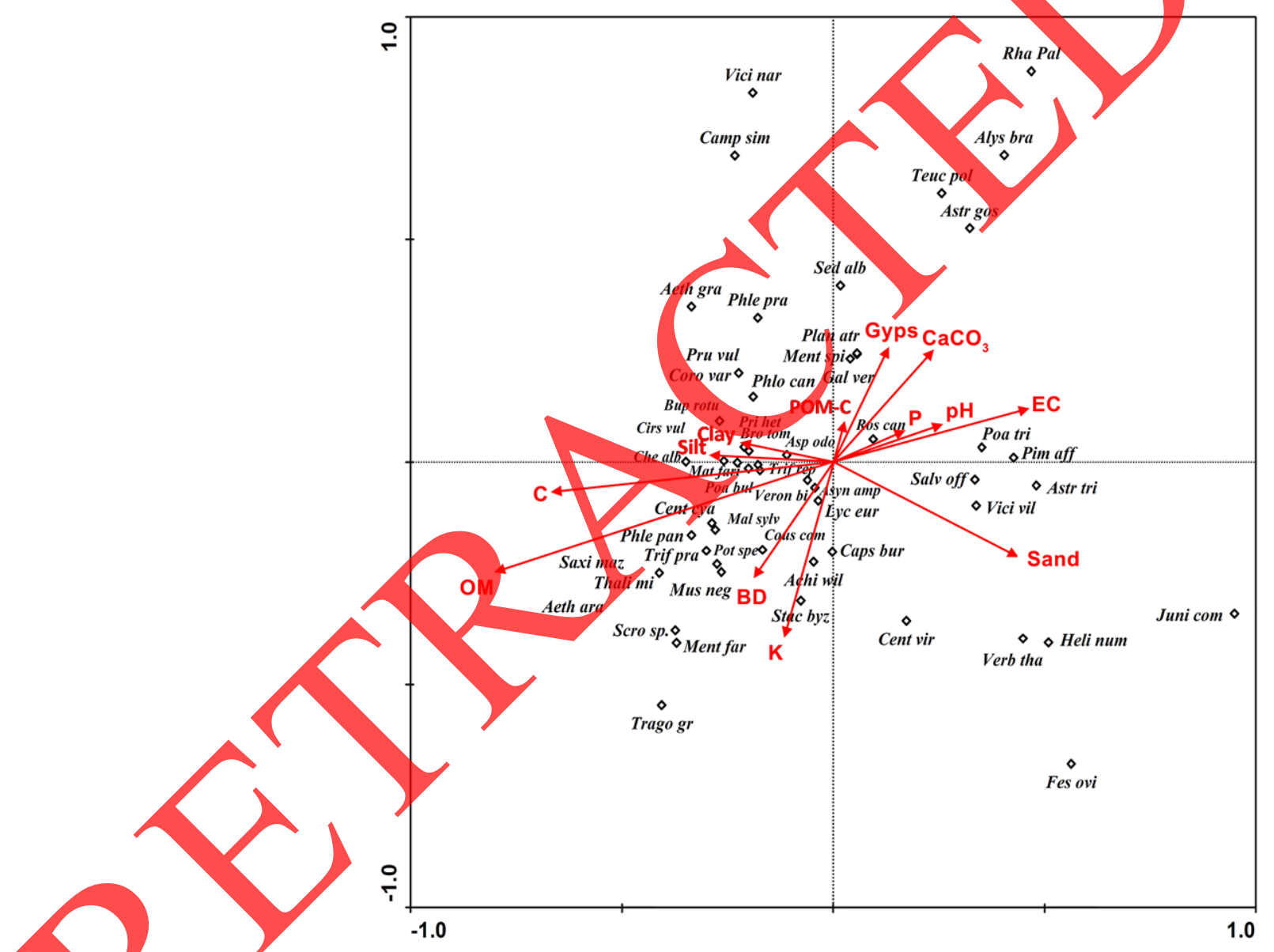

Figure 3. CCA-ordination of species in relation to Soil factors in second layer (15 - 30 $\mathrm{cm})$.

Table 4. Results of CCA analysis for soil factors in depth $15-30 \mathrm{~cm}$.

\begin{tabular}{ccccc}
\hline Axes & $\mathrm{CCA}_{1}$ & $\mathrm{CCA}_{2}$ & $\mathrm{CCA}_{3}$ & $\mathrm{CCA}_{4}$ \\
\hline $\begin{array}{c}\text { Eigenvalue } \\
\text { Species-environment correlations }\end{array}$ & 0.59 & 0.48 & 0.44 & 0.39 \\
$\begin{array}{c}\text { Cumulative percentage variance of } \\
\text { species data }\end{array}$ & 8.5 & 15.5 & 21.8 & 27.5 \\
$\begin{array}{c}\text { Cumulative percentage variance } \\
\text { of species-environment relation }\end{array}$ & 17.1 & 31.2 & 43.9 & 55.3 \\
\hline
\end{tabular}


Table 5. Results of Monte Carlo test for species-soil correlations in first layer (0 - 15).

\begin{tabular}{cccc}
\hline Soil factors & Axis1 & Axis2 & Axis3 \\
\hline Ph & 0.25 & 0.07 & -0.15 \\
EC & 0.44 & 0.12 & -0.03 \\
OM & -0.82 & -0.23 & -0.27 \\
POMC & 0.03 & -0.08 & -0.07 \\
BD & -0.18 & -0.25 & 0.17 \\
Gyp & -0.12 & -0.24 & 0.39 \\
CaCo3 & 0.23 & 0.24 & -0.11 \\
P & 0.17 & -0.06 & 0.26 \\
K & -0.12 & -0.41 & 0.11 \\
Clay & -0.21 & 0.01 & -0.07 \\
Silt & -0.27 & 0.01 & 0.34 \\
& Abbreviations are defined in Appendix A. & \\
\hline
\end{tabular}

The results of Monte Carlo test showed that, in second layer (15 - 30) among all soil factors, Organic Matter $(P<0.01)$ was the most influential features on the distribution of plants for this area. Also this factor (OM) showed a significant positive correlation with Phleumpaniculatum, Poabulbosa, Ttifoliumpretense, Centaureacyanus, Malvasy/vestris, Veronicabiloba and significant negative correlation with Rosaconina (Figure 3).

\section{Discussion}

Phytosociological and soil studies help us to understanding the formation of plant communities and relationships. These are important because generally when we relate each other to underlying factors, make a better picture of the relationships results. The distributions of vegetation more closely resemble to the changes in the soil characteristics [8]. In this study, the relationship between soil factors with plant species was investigated to determine the most effective factors separating in three rangeland habitats; grassland, grassland-shrubland and shrubland using Canonical Correspondence Analysis (CCA).

Using multivariate analysis methods is useful in determination of relationships between species and environmental factors, because CCA was used commonly by many researchers to investigate this relationship concurrently [2] [5] [28].

Results of CCA showed that distribution of communities is correlated with some soil factors. Also among soil factors, EC (in first layer) and Organic Matter (in second layer) was the most influential features on the distribution of vegetation in three rangeland sites in the study area. In addition, soil characteristics such as pH, Gypsum and Bulk Density were the most effective for describing the distribution of vegetation in the study area.

The relation between species distribution and the characteristics of the upper mineral soil layer(s) has been reported in many scientific documents. Some researcher reported a close relationship between plant species composition and 
soil chemistry ( $\mathrm{pH}$, calcium and organic carbon) [30]. Also some researchers showed that the EC (Electrical Conductivity) was the most influential features on the distribution of vegetation Which were consistent with the results of the present study [29] [30] [31] [32] [33].

Organic matter content as a pivotal soil fertility factor can affect plant diversity. The increases in soil nutrients (OM), improvement in site conditions and decrease in soil bulk density, EC and $\mathrm{pH}$ indicated, that this condition was observed in grassland habitat. The changes were mainly attributable to the development of vegetation and interaction between soil and vegetation [34]. The results showed that organic matter content has an important role in the improvement and increasing of the soil cationic capacity [31]. Also, [35] have mentioned the important role of the organic matter in the soil improvement.

According to the results, soil characteristics such as pH, Gypsum and Bulk Density were the most effective for describing the distribution of vegetation in the study area, that this condition was observed in shrubland habitat, because the soil is poor in this habitat and most importantly, the canopy cover is the shrub and grasses are rarely in between the shrubs. The trend of decreasing the soil fertility from grassland to grass-shrub land and shrub land is like the range destruction. When soil fertility decreases, the amount of the shrub increases in the rangeland and vice versa [36] [37] [38] [39].

\section{Conclusion}

Determining the relationship between soil and plants is a useful way to better understand the ecosystem condition and can help to manage the rangeland ecosystem. In this study, three rangeland sites including grassland, grassshrub land, and shrub land were selected to determine the Relation Vegetation and some soil Physico-chemical characteristics. To remove other parameter which can affect this issue due to different elevation and aspect, three sites were placed in the ame elevation and aspect. Results showed that, trend of soil factors form grassland to grass-shrub land and to shrub land is decreasing the organic matter, \%Clay and Silt also increasing the EC, pH, Gypsum and sand. Finally, changes were in rangeland ecosystems function (nutrient cycling in the soil) because of the loss of nutrients, that result in three habitats were separated from the other.

\section{References}

[1] Leonard, S.G., Miles, R.L. and Burkhartdt, J.W. (1984) Comparison of Soil Properties Associated with Basin Wildrye and Black Greaswood in the Great Basin Region.

[2] Lundholm, J.T. and Larson, D.W. (2003) Relationships between Spatial Environmental Heterogeneity and Plant Species Diversity on a Limestone Pavement. Ecography, 26, 715-722. https://doi.org/10.1111/j.0906-7590.2003.03604.x

[3] El Bana, M.I. and Al-Mathnani, A.S. (2009) Vegetation-Soil Relationships in the Wadi Al-Hayat Area of the Libyan Sahara. Australian Journal of Basic and Applied Sciences, 3, 740-747.

[4] El Bana, M.I., Khedr, A.A., Van Hecke, P. and Bogaert, J. (2002) Vegetation Composition of a Threatened Hypersaline. Ecology, 163, 63-75. 
[5] Jafari, M., Zare Chahouki, M.A., Tavili, A., Azarnivand, H. and Zahedi Amiri, Gh. (2004) Effective Environmental Factors in the Distribution of Vegetation Types in Poshtkouh Rangelands of Yazd Province (Iran). Journal of Arid Environments, 56, 627-641.

[6] Mueller-Dombois, D.C. and Ellenberg, O.H. (1974) Aims and Methods of Vegetation Ecology. John Wiley \& Sons, London.

[7] Bednarek, R., Dziadowiec, H., Pokojska, U. and Prusinkiewicz, Z. (2005) Badaniaekologiczno-Gleboznawcze. Soil-Ecological Research. PWN, Warszawa.

[8] Kabir, M., Zafariqbal, M., Farooqi, Z.R. and Shafiq, M. (2010) Vegetation Pattern and Soil Characteristics of the Polluted Industrial Area of Karachi. Pakistan Journal of Botany, 42, 661-678.

[9] Graham, C.H., Smith, T.B. and Languy, M. (2005) Current and Historical Factors Influencing Patterns of Species Richness and Turnover of Birds in the Gulf of Guinea Highlands. Journal of Biogeography, 32, 1371-1384. https://doi.org/10.1111/j.1365-2699.2005.01284.x

[10] Engler, R. and Guisan, A. (2009) MIGCHIM: Predicting Plant Distribution and Dispersal in a Changing Climate. Diversity and Distributions Journal, 15, 590-601. https://doi.org/10.1111/j.1472-4642.2009.00566.x

[11] Ukpong, I.E. (1994) Soil-Vegetation Interrelationships of Mangrove Swamps as Revealed by Multivariate Analyses. Geoderma, 64, 167-181.

[12] Dodd, M.B., Lauenroth, W.K., Burke, I.C. and Chapman, P.L. (2002) Association between Vegetation Patterns and Soil Texture in the Shortgrass Steppe. Plant Ecology, 158, 127-137. https:/(doi.org/10.1023/A:1015525303754

[13] Medinski, T. (2007) Soil Physical and Chemical Properties and Their Influence on the Plant Species Richness of Arid, South-Western Africa. Thesis Presented for the Degree of Master of Science in Conservation Ecology, University of Stellenbosch, Stellenbosch.

[14] Cannone, N., Wagner, D., Hubberten, H.W. and Guglielmin, M. (2008) Biotic and Abiotic Factors Influencing Soil Properties across a Latitudinal Gradient in Victoria Land, Antarctica. Geoderma, 144, 50-65.

[15] Zare, S., Jafari, M., Tavili, A., Abbasi, H. and Rostampour, M. (2011) Relationship between Environmental Factors and Plant Distribution in Arid and Semi-Arid Area (Case Study: Shahriyar Rangelands, Iran). American-Eurasian Journal of Agricultural \& Environmental Sciences, 10, 97-105.

[16] Abbadi, A.G. and El-Sheikh, A.M. (2002) Vegetation Analysis of Failaka Island. Journal of Arid Environments, 50, 153-165.

[17] Wei, Q.L., Liu, X.J., Ajmal Khan, M. and Gul, B. (2008) Relationship between Soil Characteristics and Halophytic Vegetation in Coastal Region of North China. Pakistan Journal of Botany, 40, 1081-1090.

[18] JafarianJeloudar, Z., Arzani, H., Jafari, M. Kavian, A., Zahedi, Gh. and Azarnivand, H. (2010) Vegetation Community in Relation to the Soil Characteristics of Rineh Rangeland, Iran. Caspian Journal of Environmental Sciences, 8, 141-150.

[19] Iwara, A.I., Gani, B.S., Njar, G.N. and Deekor, T.N. (2011) Influence of Soil Physico-Chemical Properties on the Distribution of Woody Tree/Shrub Species in SouthSouthern Nigeria. Journal of Agricultural Science, 2, 69-75.

[20] DianatiTilaki, G.A., Naderi Nasrabad, H. and Abdollahi, J. (2011) Investigation of Relationship between Vegetation, Topography and Some Soil Physico-Chemical Characteristics in Nodoushan Rangelands of Yazd Province (Iran). International Journal of Natural Resources and Marine Sciences, 1, 147-156. 
[21] Amanollahi, J., Makmom Abdullah, A. and Dianati Tilaki, G.A. (2011) Relationship between Plants Evening and Soil Properties in the Rangeland, Lar National Park, Iran. African Journal of Agricultural Research, 6, 5551-555.

[22] Kargar Chigani, H., Khajeddin, S.J. and Karimzadeh, H.R. (2012) Soil-Vegetation Relationships of Three Arid Land Plant Species and Their Use in Rehabilitating Degraded Sites. Land Degradation \& Development, 23, 92-101. https://doi.org/10.1002/ldr.1057

[23] Mousaei Sanjereheia, M., Jafarib, M., Matajic, A., BaghestaniMeybodi, N. and Bihamtae, M.R. (2013) Influence of Environmental Factors on Distribution of Plant Species in Nodushan Rangelands of Yazd Province (Iran). DESERT, 18, 19-26.

[24] Abd El-Ghani, M.M. (2000) Vegetation Composition of Egyptian Inland Salt Marshes. Botanical Bulletin-Academia Sinica Taipei, 41, 305-314.

[25] Folster, H., Dezzeo, N. and Priess, J.A. (2001) Desert and Vegetation Environment Relationships in Kirthar National Park. Sindth Pakistan. Journal of Arid Environments, 61, 397-418.

[26] Palmer, M.W. (1993) Putting Thing in anEven Better Order: The Advantages of Canonical Correspondence Analysis, Ecology, 74, 2215-2230. https://doi.org/10.2307/1939575

[27] TerBraak, C.J.F. and Smilauer, P. (1998) Canoco Reference Manual and User's Guide to Canoco for Windows. Microcomputer Power, Ithaca, USA. 352 p two different periods. Geoderma, $119 \mathrm{p}$.

[28] Abd El-Ghani, M.M. and Amwe, W.A. (2003) Soil-Vegetation Relationships in a Costal Desert Plain of Southern Sinai, Egypt. Journal of Arid Environments, 55, 607-628.

[29] Abd El-Ghani M.M. (1998) Environmental Correlates of Species Distribution in Arid Desert Ecosystems of Eastern Egypt. Journal of Arid Environments, 38, 297-

[30] Carneval, N.J. and Torres, P.S. (1990) The Relevance of Physical Factors on Species Distribution in Inland Salt Marshes (Argentina). Coenoses, 5, 113-120.

[31] Abd El-Ghani M. and Amer, W.M. (2003) Soil-Vegetation Relationships in a Coastal Desert Plain of Southern Sinai, Egypt. Journal of Arid Environments, 55, 607-628. Jafari, M., Rostampour, M., Tavili, A., Zare Chahouki, M.A. and Farzadmehr, J. (2008) Direct Gradient Analysis of Plant Species and Environmental Factors in Ecological Groups, Case Study: Zirkouh Rangelands of Qaen. Rangeland Journal, 2, 329-343. (In Persian)

[33] Yari, R., Azarnivand, H., Zare Chahouki, M.A. and Farzadmehr, J. (2012) Relationship between Species Diversity and Environmental Factors in Sarchah Amari Ranglands of Birjand. Iranian Journal of Range and Desert Research, 19, 95-107.

[34] Liu, Z., Fu, B., Zheng, X. and Liu, G. (2010) Plant Biomass, Soil Water Content and Soil N:P Ratio Regulating Soil Microbial Functional Diversity in a Temperate Steppe: A Regional Scale Study. Soil Biology \& Biochemistry, 42, 45-450.

[35] Azarnivand, H., Jafari, M., Moghadam, M.R., Jalili, A. and Zare Chahoki, M. (2003) Survey of Soil Specification Effects and Elevation Changes over Distribution of Two Species of Artemisia, Case Study: Range Land of Verv Avard, Garmsar, and Semnan regions. Iranian Journal of Natural Resources, 56, 93-99.

[36] Cheng, X., An, S., Chen, J., Li, B., Liu, Y. and Liu, S. (2007) Spatial Relationship among Species Above-Ground Biomass, $\mathrm{N}$ and $\mathrm{P}$ in Degraded Grassland in Ordos Plateau, Northwestern China. Journal of Arid Environments, 68, 652-667.

[37] Li, X.R., Jia, X.H. and Dang, G.R. (2006) Influence of Desertification on Vegetation 
Pattern Variation in the Cold Semi-Arid Grassland of Qinghai-Tibet Plateau, North-West China. Journal of Arid Environments, 64, 505-522.

[38] Norton, J.B., Monaco, T.A., Norton, J.M., Johnson, D.A. and Jones, T.A. (2004) Soil Morphology and Organic Matter Dynamics under Cheatgrass and Sagebrushsteppe Plant Communities. Journal of Arid Environments, 57, 445-466.

[39] Wang, J., Fu, B., Qiu, Y. and Chen, L. (2003) Soil Nutrients in Relation to Land Use and Landscape Position in the Semi-Arid Small Catchments on the Loss Plateau in China. Journal of Arid Environments, 48, 537-550.

\section{Abbreviations}

Abbreviations of the plant species and Soil factors in the tables and figures.

\begin{tabular}{|c|c|c|c|c|c|}
\hline Achiwilh & Achilleawilhelmsii & Galiver & Galiumverum & Rha Pall & RhamnusPallasii \\
\hline Aetharab & Aethionemaarabicum & Helinum & anthemumnummularium & Ros can & Rosa canina \\
\hline Alys bra & Alyssum bracteatum & Helicplic & sstmplicatum & Salvaeth & Salvia aethiopis \\
\hline Aspe odor & Asperulaodorata & & Juniperuscommunis & Salvoffi & Salvia officinalis \\
\hline Astraego & & & Lycopuseuropaeus & Scro sp. & Scrophularia sp. \\
\hline Astrstrib & & & Malvasylvestris & Scut tour & Scutellariatournefortii \\
\hline Asynampl & & & Matthiola farinose & Sedualb & Sedum album \\
\hline Bro tom & & 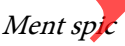 & Menthaspicata & Stacbyz & Stachysbyzanthina \\
\hline Buprotu & & Musneg & Muscarineglectum & Stac lava & Stachyslavandulifolia \\
\hline Camp simp & & & Nepetacrassifolia & Teucpoli & Teucriumpolium \\
\hline Caps burs & & Phle pan & Phleumpaniculatum & Thal tum & Thalictrumtumens \\
\hline Cent cya & & Phle pre & Phleum pretense & Traggra & Tragopogongraminifolius \\
\hline Cent & Centaur & Phlo can & Phlomiscancellata & Trifpra & Trifolium pretense \\
\hline Chen & Chenopodium album & Plan atr & Plantagoatrata & Trif rep & Trifoliumrepens \\
\hline Cirsvul & Cirsiamvulgare & Poabul & Poabulbosa & Verb tha & Verbascum Thapsus \\
\hline Coro var & & Poatri & Poatrivalis & Vero ana & Veronica anagalis \\
\hline Cous com & Cousinia commutate & Pota spec & Potentillaspeciosa & Vero auc & Veronica aucheri \\
\hline Cous com & Cousinia commutate & Pote rec & Potentilla recta & Vero bilo & Veronica biloba \\
\hline Dian orie & Dianthus orientalis & Prihete & Primulaheterochroma & Viciper & Viciapersica \\
\hline Fes ovi & Festucaovina & Prunvul & Prunella vulgaris & & \\
\hline $\mathrm{pH}$ & Acidity & POMC & $\begin{array}{c}\text { particulate organic } \\
\text { matter-carbon }\end{array}$ & $\mathrm{CaCo}_{3}$ & Calcium carbonate \\
\hline
\end{tabular}


Submit or recommend next manuscript to SCIRP and we will provide best service for you:

Accepting pre-submission inquiries through Email, Facebook, LinkedIn, Twitter, etc. A wide selection of journals (inclusive of 9 subjects, more than 200 journals)

Providing 24-hour high-quality service

User-friendly online submission system

Fair and swift peer-review system

Efficient typesetting and proofreading procedure

Display of the result of downloads and visits, as well as the number of cited articles Maximum dissemination of your research work

Submit your manuscript at: http://papersubmission.scirp.org/ Or contact oje@scirp.org

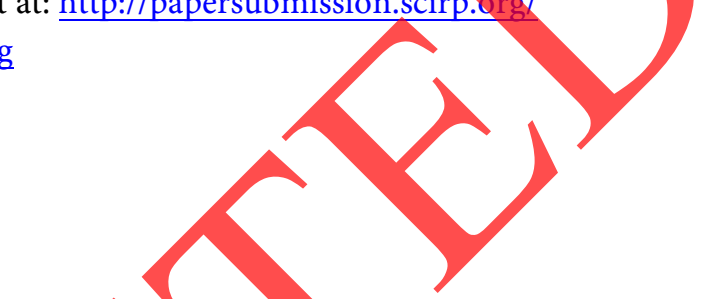

